\title{
PENGARUH MANAJEMEN MODAL KERJA TERHADAP GROSS OPERATING PROFIT PERUSAHAAN MANUFAKTUR DI BURSA EFEK INDONESIA TAHUN 2014-2018
}

\author{
Tommy \\ Program Studi Magister Manajemen Universitas Tarumanagara \\ tommysun159@gmail.com
}

Masuk : 07-06-2020, revisi : 08-07-2020 diterima untuk diterbitkan : 09-07-2020

\begin{abstract}
The purpose of this study was to analyze the Effect of Working Capital Management on Gross Operating Profit in Manufacturing Companies in the Indonesia Stock Exchange in 2014-2018. This study uses a quantitative approach with an associative method to determine whether there is an influence from account receivable period, account payable period, account inventory period, cash conversion cycle to gross operating profit with financial debt ratio and sales growth as proxies and verification method that is testing the hypotheses perform based on data. This study uses a sample of 33 manufacturing companies on the stock exchange as panel data. The results of this study indicate that partially and simultaneously the account receivable period, account inventory period, account inventory period, cash conversion cycle with financial debt ratio and sales growth as proxies has a positive and significant effect on gross operating profit on manufacturing companies listed on the Indonesia Stock Exchange during the 2014-2018 research period.
\end{abstract}

Keywords: Account Inventory Period, Account Payable Period, Account Receivable Period, Cash Conversion Cycle, Financial Debt Ratio, Gross Operating Profit, Working Capital Management, Sales Growth

Abstrak: Tujuan penelitian ini adalah untuk menganalisis Pengaruh Manajemen Modal Kerja Terhadap Gross Operating Profit pada Perusahaan Manufaktur di Bursa Efek Indonesia Tahun 2014-2018. Penelitian ini menggunakan pendekatan kuantitatif dengan metode asosiatif untuk mengetahui ada tidaknya pengaruh dari account receivable period, account payable period, account inventory period, cash conversion cycle terhadap gross operating profit dengan proksi finansial debt ratio dan sales growth dan menggunakan metode verifikatif yaitu menguji kinerja hipotesa berdasarkan data. Penelitian ini menggunakan sampel 33 perusahaan manufaktur di bursa efek sebagai data panel. Hasil penelitian ini menunjukkan secara parsial dan simultan account receivable period, account inventory period, account inventory period, cash conversion cycle dengan proksi financial debt ratio dan sales growth berpengaruh positif dan signifikan terhadap gross operating profit pada perusahaan manufaktur yang tercatat di Bursa Efek Indonesia selama periode penelitian 2014-2018.

Kata kunci: Account Inventory Periode, Account Payable Period, Account Receivable Period, Cash Conversion Cycle, Financial Debt Ratio, Gross Operating Profit, Manajemen Modal Kerja, dan Pertumbuhan Penjualan.

\section{PENDAHULUAN}

\section{Latar Belakang}

Penelitian yang akan dilakukan oleh penulis merupakan replikasi dari penelitian yang dilakukan Toan et. al., (2017) di Vietnam terhadap 34 perusahaan konstruksi serta penelitian Evci dan Sak (2018), sedangkan peneliti menganalisis 33 perusahaan manufaktur di Bursa Efek Indonesia Tahun 2014-2018. Penelitian Toan et.al (2017), menjelaskan bahwa setiap perusahaan membutuhkan dana dalam mengembangkan usahannya. Pemenuhan dana tersebut dapat berasal dari dana sendiri, hutang jangka pendek maupun jangka panjang serta modal 
saham. Faktor yang bisa mempengaruhi modal kerja dalam penelitian Toan et.al (2017) menemukan hubungan yang positif antara Gross Operating Profit dengan FDR, FFAR dan SG. Sementara CCC, ARP, APP, AIP memiliki hubungan yang negatif terhadap Gross Operating Profit. Sedangkan Penelitian yang serupa di Indonesia dilakukan pada tahun yang sama oleh Telly dan Ansori (2017) terhadap perusahaan manufaktur dan real estate pada periode 20102014 memiliki hasil yang berbeda yaitu cash conversion cycle memiliki pengaruh positif terhadap profitabilitas. Oleh karenanya penelitian ini membuktikan analisa Pengaruh Manajemen Modal Kerja Terhadap Gross Operating Profit Perusahaan Manufaktur di Bursa Efek Indonesia Tahun 2014-2018 dengan variabel variabel independen account receivable period, account payable period, account inventory period, cash conversion cycle, dengan variabel dependen gross operating profit serta proksi financial debt ratio, sales growth apakah sejalan dengan penelitian Toan et. al., (2017) ataukah sejalan dengan Telly dan Ansori (2017). Berdasarkan data tersebut didapatkan adanya perbedaan hasil penelitian terdahulu tentang manajemen modal kerja, maka peneliti tertarik untuk meneliti menggunakan variabel modal kerja pada perusahaan manufaktur di Indonesia.

Tujuan Penelitian

Tujuan dalam penelitian ini adalah untuk menganalisis Account Receivable Period, Account Payable Period, Account Inventory Period, Cash Conversion Cycle, terhadap Gross Operating Profit pada Perusahaan Manufaktur di Bursa Efek Indonesia Tahun 2014-2018.

\section{TINJAUAN PUSTAKA}

Penelitian Toan et.al, (2017) dihasilkan ARP memiliki hubungan negatif dan signifikan terhadap GOP, hal ini menunjukkan bahwa semakin tinggi ARP, semakin rendah profitabilitas. Hal ini mengindikasikan bahwa semakin pendek waktu yang dibutuhkan untuk menerima pembayaran piutang, maka semakin tinggi tingkat profitabilitas perusahaan. Maka hipotesis yang diajukan peneliti sebagai berikut:

\section{H1: Terdapat Pengaruh Account Receivable Period terhadap Gross Operating Profit}

Penelitian Evci dan Sak (2018) menyatakan bahwa variabel Account Payable Period (APP) berpengaruh negatif dan signifikan terhadap profitabilitas. Hal ini mengindikasikan bahwa hubungan antara Account Payable Period berlawanan arah dengan profitabilitas, artinya semakin tinggi Account Payable Period, maka akan menurunkan GOP, dan sebaliknya. Hal ini menunjukkan semakin lama waktu yang dibutuhkan untuk membayar hutang, maka perusahaan kehilangan kesempatan untuk memperoleh potongan harga dari kebijakan pembelian kredit dari pihak penjual. Maka hipotesis yang diajukan peneliti sebagai berikut:

\section{$\mathrm{H}_{2}$ : Terdapat Pengaruh Account Payable Period terhadap Gross Operating Profit}

Penelitian Hoang (2015), menyatakan bahwa variabel Account Inventory Period (AIP) berpengaruh negatif terhadap profitabilitas. Hal ini mengindikasikan bahwa hubungan antara Account Inventory Period berlawanan arah dengan profitabilitas. Dapat diartikan bahwa jika persediaan lebih lama untuk dapat terjual maka akan menurunkan profitabilitas perusahaan dalam hal ini Gross Operating Profit (GOP). Maka hipotesis yang diajukan peneliti sebagai berikut:

\section{H3: Terdapat Pengaruh Account Inventory Period terhadap Gross Operating Profit}

Berdasarkan penelitian Evci dan Sak (2018), dan Rezaei \& Pourali (2015), menemukan adanya hubungan signifikan negatif antara CCC, yang berarti kenaikan atau penurunan CCC terhadap Profitabilitas sangat berpengaruh secara signifikan. Sementara penelitian Telly dan Ansori (2017) Pengaruh ukuran dan Cash Conversion Cycle Terhadap Profitabilitas Perusahaan, dengan hasilnya menunjukkan bahwa cash conversion cycle memiliki pengaruh terhadap profitabilitas, artinya perputaran kas yang berpengaruh positif berdampak terhadap peningkatan keuntungan perusahaan. Maka hipotesis yang diajukan peneliti sebagai berikut:

H4: Terdapat Pengaruh Cash Conversion Cycle (CCC) terhadap Gross Operating Profit 


\section{METODOLOGI PENELITIAN}

Penelitian ini menggunakan pendekatan kuantitatif dengan metode asosiatif untuk mengetahui ada tidaknya pengaruh dari account receivable period, account payable period, account inventory period, cash conversion cycle terhadap gross operating profit dengan proksi finansial debt ratio dan sales growth dan menggunakan verifikatif yaitu menguji kinerja hipotesa berdasarkan data. Dimana Hipotesa penelititian ini sebagai berikut :

H1 : Terdapat Pengaruh Account Receivable Period terhadap Gross Operating Profit H2 : Terdapat Pengaruh Account Payable Period terhadap Gross Operating Profit H3 : Terdapat Pengaruh Account Inventory Period terhadap Gross Operating Profit H4 : Terdapat Pengaruh Cash Conversion Cycle (CCC) terhadap Gross Operating Profit

Pengujian hipotesis dimaksudkan untuk mengetahui ada tidaknya pengaruh yang signifikan antara variabel independen kepada variabel dependen. Dalam pengujian hipotesis ini, penulis menetapkan dengan menggunakan uji signifikan, dengan penetapan hipotesis nol (Ho) dan hipotesis alternatif (Ha).

$\mathrm{H}_{0}$ : variabel independen tidak berpengaruh terhadap variabel dependen.

$\mathrm{H}_{\mathrm{a}}$ : variabel independen berpengaruh terhadap variabel dependen.

Dengan kriteria keputusan sebagaai berikut:

1. Jika sig. nilai probabilitas t lebih besar dari tingkat signifikansi (alpha) 0,05 maka $\mathrm{H}_{0}$ diterima, artinya secara parsial variabel independen memiliki pengaruh terhadap variabel dependen.

2. Jika sig. probabilitas t lebih kecil dari tingkat signifikansi (alpha) 0,05 maka $\mathrm{H}_{0}$ ditolak, artinya secara parsial variabel independen tidak memiliki pengaruh terhadap variabel dependen.

Pengujian ini dilakukan secara simultan (uji F) maupun secara parsial (uji t). Metode analisis data yang digunakan untuk menganalisis variabel-variabel yang mempengaruhi leverage adalah multiple panel regression atau regresi linier berganda data panel yaitu analisis regresi gabungan antara data cross section dan data time series yang memprediksi nilai intersep dan slope. Analisis regresi ini bertujuan untuk menguji pengaruh dua atau lebih variabel independen terhadap satu variabel dependen. Persamaan regresi penelitian ini adalah:

Model 1 GOP $_{\text {it }}=\beta_{0 i t}+\beta_{1 i t} \mathbf{A R P}_{2 i t}+\beta_{1 i t}$ FD $_{3 i t}+\beta_{1 i t} S_{4} 4$ it $+E_{\text {it }}$

Model 2 GOP $_{\text {it }}=\beta_{0 i t}+\beta_{1 i t} \mathrm{APP}_{2 i t}+\beta_{1 i t}$ FD $_{3 i t}+\beta_{1 i t} S_{4} 4 i t+E_{i t}$

Model 3 GOP $_{\text {it }}=\beta_{0 i t}+\beta_{1 i t} \mathrm{AIP}_{2 \text { it }}+\beta_{1 i t}$ FD $_{3 i t}+\beta_{1 i t} \mathrm{SG}_{4 i t}+\mathrm{E}_{\text {it }}$

Model 4 GOP $_{\text {it }}=\beta_{0 i t}+\beta_{1 i t} \mathrm{CCC}_{2 i t}+\beta_{1 i t}$ FD $_{3 i t}+\beta_{1 i t} S_{4 i t}+E_{i t}$

Populasi dan Sampel

Populasi penelitian ini adalah perusahaan manufaktur yang terdaftar di Bursa Efek Indonesia. Metode penarikan sampel yang dilakukan dalam penelitian ini dengan cara purposive sampling, dengan kriteria, Perusahaan manufaktur yang terdaftar di Bursa Efek Indonesia, Perusahaan yang telah mempublikasikan laporan keuangan tahunan, dan tidak mengalami delisting selama periode tertentu.

Tabel 1

Jumlah Sampel Penelitian

\begin{tabular}{lc}
\hline \multicolumn{1}{c}{ Keterangan } & Jumlah \\
\hline Perusahaan manufaktur yang didownload peneliti & 65 \\
Perusahaan manufaktur yang laporan tahunan tidak lengkap & $(25)$ \\
Perusahaan manufaktur yang tidak sesuai dengan variabel & $(7)$ \\
Jumlah perusahaan yang dapat di jadikan sampel & $\mathbf{3 3}$ \\
Jumlah observasi (5 tahun x 33 Perusahaan) & $\mathbf{1 6 5}$ \\
\hline
\end{tabular}




\section{Variabel Operasional}

Tabel 2

Variabel Operasional

\begin{tabular}{|c|c|c|}
\hline Variabe! & Konsep Variabel & Indikator \\
\hline $\begin{array}{l}\text { Accoust } \\
\text { Recehable } \\
\text { Period }\end{array}$ & $\begin{array}{l}\text { Perbandingan untuk menghasilkan rerata jangka } \\
\text { waltu vane diperlukan dalam mengelola piutang } \\
\text { perusahaan. ARP menggambarkan adanya kredit } \\
\text { macet yang terdapat di dalam laporan keuangan } \\
\text { perusahaan dan kemampuan perusahaan untuk } \\
\text { mengubah piutang usaha menjadi kas dan setara kas }\end{array}$ & $\begin{array}{l}\frac{365}{\text { Net Sales / Short Ferm ARP }} \\
\text { Toan et.al., (2017) }\end{array}$ \\
\hline $\begin{array}{l}\text { Accownt } \\
\text { Pavable } \\
\text { Period }\end{array}$ & $\begin{array}{l}\text { APP menupakan salah satu metode mempersingkat } \\
\text { putaran kas dengan cara memperpanjang waktu } \\
\text { pembayaran }\end{array}$ & $\begin{array}{l}\frac{365}{\text { Sellong Cost.Account Panable }} \\
\text { Toan et.al. (2017) }\end{array}$ \\
\hline $\begin{array}{l}\text { Accowit } \\
\text { Bwentony } \\
\text { Period }\end{array}$ & $\begin{array}{l}\text { AIP merupakan perbandingan harga barang pokok } \\
\text { terhadap ketersedian barang di perusahaan }\end{array}$ & $\begin{array}{l}\frac{365}{\text { Selling Cost/wentory }} \\
\text { Toan et.al. (2017) }\end{array}$ \\
\hline $\begin{array}{l}\text { Cash } \\
\text { conversion } \\
\text { cycle }\end{array}$ & $\begin{array}{l}\text { Cosh comersion cycle atau siklus konvers kas } \\
\text { memusatkan pada lamanya waitu antara saat } \\
\text { perusahaan melakukan pembayaran dan saat } \\
\text { perusahaan menerima kembali arus kas masuk }\end{array}$ & $\begin{array}{l}C C C=(A R P+A I P)-A P P \\
\text { Toan et.al. }(\mathbf{2 0 1 7})\end{array}$ \\
\hline $\begin{array}{l}\text { Fbnaxial } \\
\text { Debt Ratio }\end{array}$ & $\begin{array}{l}\text { Flnacial debt ratio yang selanjutnya disebut FD, } \\
\text { menurut pendapat Lazardis dan Trvfonidis }(2006) \text {, } \\
\text { perusahaan akan mendapatkan laba dari APR dalam } \\
\text { rangka mengurangi CCC perusahaan dan } \\
\text { meninglcatkan hasil profitabilitas }\end{array}$ & $\begin{array}{l}\text { Short Term Loans + Long Ferms } \\
\text { Loavs } \\
\text { Total Assets } \\
\text { Toan et.al. (2017) }\end{array}$ \\
\hline $\begin{array}{l}\text { Sales } \\
\text { Growth }\end{array}$ & $\begin{array}{l}\text { Growth merupakan rasio pertumbuhan merupakan } \\
\text { perbandingan yang menumiulkan kemampuan } \\
\text { perusahaan dalam mempertahankan posisinya di } \\
\text { dunia industri dan perekonomian }\end{array}$ & $\begin{array}{l}\text { This Years Sales - Previous Year } \\
\text { Sales Provious Years Sales } \\
\text { Toan et.al., (2017) }\end{array}$ \\
\hline $\begin{array}{l}\text { Gross } \\
\text { Operating } \\
\text { Profit }\end{array}$ & $\begin{array}{l}\text { Gross Operoting Profit adalah tingkat kemampuan } \\
\text { perusahaan untuk memperoleh keuntungan dari total } \\
\text { aset vang dimiliki }\end{array}$ & $\begin{array}{l}\frac{\text { Sales }- \text { Cost Of Goods }}{\text { Total Aset }} \\
\text { Toan et.al. (2017) }\end{array}$ \\
\hline
\end{tabular}

HASIL PENELITIAN

Uji Chow/Restricted F-Test

Tabel 3

Pengujian Uji Chow/Restricted F-Test

\begin{tabular}{lccc}
\hline Chow Test & $\begin{array}{c}\text { Probabilita Chi- } \\
\text { Square }\end{array}$ & Keputusan & Keterangan \\
\hline Model ARP & 0,0000 & Ho ditolak & Fixed effect \\
Model APP & 0,0000 & Ho ditolak & Fixed effect \\
Model AIP & 0,0000 & Ho ditolak & Fixed effect \\
Model CCC & 0,0000 & Ho ditolak & Fixed effect \\
\hline
\end{tabular}

Kriteria Uji Chow

$\mathrm{H} 0$ : Common Effect

$\mathrm{H} 1$ : Fixed Effect

Hasil redundant fixed effect ataulikelihood ratio untuk model ini memiliki nilai probabilitas F sebesar 0,0000 lebih kecil dari tingkat signifikansi (alpha) 0,05, sehingga H0 ditolak dan H1 diterima, model yang sesuai dari hasil ini adalah fixed effect.

Uji Hausman Test

\section{Tabel 4}

Hasil Pengujian Hausman Test

\begin{tabular}{lccc}
\hline Hausman Test & $\begin{array}{c}\text { Probabilita Chi- } \\
\text { Square }\end{array}$ & Keputusan & Keterangan \\
\hline Model ARP & 0.0087 & Ho ditolak & Fixed effect \\
Model APP & 0.0005 & Ho ditolak & Fixed effect \\
Model AIP & 0,0095 & Ho ditolak & Fixed effect \\
Model CCC & 0,0103 & Ho ditolak & Fixed effect \\
\hline
\end{tabular}

H0 : Model mengikuti random effect

H1 : Model mengikuti fixed effect 
Berdasarkan hasil uji hausman menunjukkan nilai probabilitas lebih kecil dari tingkat signifikansi (alpha) 0,05, maka H0 ditolak dan H1 diterima, sehingga dapat diartikan bahwa model fixed effects modal yang tepat digunakan

\section{Pengujian Simultan}

Tabel 5

Hasil Uji Simultan

\begin{tabular}{lcc}
\hline Hausman Test & F-stat & Prob F-stat \\
\hline Model ARP & 4.4814 & 0,000 \\
Model APP & 4.4294 & 0,000 \\
Model AIP & 4.8774 & 0,000 \\
Model CCC & 4.7946 & 0,000 \\
\hline
\end{tabular}

Untuk pengujian simultan baik pada model ARP, APP, AIP dan CC diperoleh nilai probabilitas dari F statistic sebesar 0,000 lebih kecil dari tingkat signifikansi (alpha) 0,05 untuk keempat model sehingga Ho ditolak (Ha diterima) dan dapat disimpulkan terbukti pada keempat model yaitu model ARP, APP, AIP dan CCC keseluruhan variabel independen berpengaruh signifikan terhadap variable dependennya.

\section{Pembahasan}

\section{H1: ARP berpengaruh positif dan signifikan terhadap GOP}

Nilai dari prob t stastistik variable 0,000686 sebesar $0,0022<0,05$ (alpha) menunjukkan ARP berpengaruh positif dan signifikan terhadap GOP. Hasil ini sejalan dengan penelitian Lestari (2014), Chary et al. (2011), Rajesh et al. (2011), dimana perusahaan yang mampu mengelola kebijakan piutang perusahaan dengan memberikan waktu pembayaran lebih panjang dapat meningkatkan keuntungan perusahaan. Calon pembeli yang sebelumnya tidak bisa membeli karena siklus penjualan yang panjang, sekarang mendapat kesempatan membelinya.

\section{H2: APP berpengaruh positif dan signifikan terhadap GOP}

Nilai dari prob t stastistik variable 0,001367 sebesar $0,0000<0,05$ (alpha) menunjukkan APP berpengaruh positif dan signifikan terhadap GOP. Hal ini sejalan dengan penelitian EL Maude (2016), yang artinya perusahaan yang mampu menunda pembayaran hutangnya lebih lama dapat meningkatkan laba perusahaan. Dengan menunda pembayaran hutang, dana yang peruntukan-nya membayar hutang dapat digunakan untuk membeli bahan baku untuk meningkatkan produktivitas.

\section{H3: AIP berpengaruh positif dan signifikan terhadap GOP.}

Nilai dari prob t stastistik variable 0,000933 sebesar 0,0001 <0,05 (alpha) menunjukkan Account Inventory Period berpengaruh positif dan signifikan terhadap Gross Operating Profit artinya semakin tinggi periode perputaran persediaan maka akan meningkatkan profitabilitas perusahaan. Tingginya periode perputaran persediaan dapat disebabkan karena tingginya tingkat produktivitas yang tidak diikuti dengan tingginya tingkat penjualan. Hal ini dikarenakan semakin banyak barang yang diproduksi, maka semakin besar nilai tambah (value added) yang dihasilkan atas barang jadi yang diproduksi. Nilai tambah dari hasil produksi akan menekan harga pokok penjualan dan meningkatkan GOP perusahaan.

\section{H4: CCC berpengaruh positif dan signifikan terhadap GOP}

Nilai dari prob t stastistik variable 0.000592 sebesar $0,0002<0,05$ (alpha) menunjukkan bahwa Ho ditolak (Ha diterima) sehingga disimpulkan CCC berpengaruh positif dan signifikan terhadap GOP. Artinya adanya pengaruh yang positif berarti bahwa semakin tinggi perputaran kas maka keuntungan yang diperoleh perusahaan juga akan semakin tinggi. Perputaran kas perusahaan harus dikelola dengan tepat, dimulai dari kebijakan penagihan piutang, kebijakan perputaran persediaan dan kebijakan pembayaran hutang. 


\section{KESIMPULAN}

Penelitian ini bertujuan untuk mengetahui apakah terdapat pengaruh yang signifikan dari Account Receivable Period, Account Payable Period, Account Inventory Period, Cash Conversion Cycle dengan variabel kontrol Financial Debt Ratio dan Sales Growth terhadap Gross Operating Profit pada perusahaan manufaktur yang tercatat di Bursa Efek Indonesia selama periode penelitian 2014-2018. Kesimpulan yang dapat diambil dari hasil penelitian ini adalah sebagai berikut: Secara parsial dan simultan account receivable period, account inventory period, account inventory period, cash conversion cycle dengan variabel kontrol financial debt ratio dan sales growth terhadap gross operating profit berpengaruh postif dan signifikan pada perusahaan manufaktur yang tercatat di Bursa Efek Indonesia selama periode penelitian 2014-2018.

\section{DAFTAR PUSTAKA}

Brigham, E. F., \& Houston, J. F. (2010). Dasar-dasar Manajemen Keuangan (Edisi 11, Buku 1) (Ali Akbar Yulianto, Trans.). Jakarta: Salemba Empat

El-Maude, J. G., \& Shuaib, A. (2016). Empirical examination of the association of working capital management and firms' profitability of the listed food and beverages firms in Nigeria. Journal of Arts, Science \& Commerce, 7. Diunduh pada tanggal 20 September 2019, dari https://www.researchgate.net/ publication/307782484_

Evci, S., \& Sak, N. (2018). The effect of working capital management on profitability in emerging countries: Evidence from Turkey. Journal Financial Management from an Emerging Market Perspective. Diunduh pada tanggal 20 September 2019, dari https://www.intechopen.com/predownload/57069

Hoang, T. V. (2015). Impact of working capital management on firm profitability: The case of listed manufacturing firms on Ho Chi Minh stock exchange. Journal Asian Economic and Financial Review, AESS Publication. Diunduh pada tanggal 20 September 2019, dari http://www.aessweb.com/pdf-files/aefr-2015-5(5)-779-789.pdf

Jumingan. (2011). Analisis Laporan Keuangan. Jakarta: Bumi Aksara.

Kasmir. (2014). Analisis Laporan Keuangan. Jakarta: Raja Grafindo Persada.

Lazaridis, I. \& Tryfonidis. (2006). The relationship between working capital management and profitability of listed companies in the Athens stock exchange. Journal of Business Finance \& Accounting, 19(1). Diunduh pada tanggal 20 September 2019, dari http://ssrn.com/abstract=931591

Toan, L. D., Nhan, H. V., Ngoc Anh, L. N. \& Man, L. Q. (2017). The relationship between working capital management and profitability: Evidence in Vietnam. Journal of Business and Management, 12(8). Diunduh pada tanggal 20 September 2019, dari http://www.ccsenet.org/journal/index.php/ijbm/article/download/67780/37820 